\title{
BAHASA RUPA PADA RELIEF EROTIS DI PURA MEDUWE KARANG
}

\author{
(Visual Language on Erotic Relief in Meduwe Karang Temple)
}

Eldi Khairul Akbar, Coleta Palupi Titasari, dan I Wayan Srijaya

Mahasiswa Arkeologi Universitas Udayana, Dosen Arkeologi Universitas Udayana

dan Dosen Arkeologi, Fakultas Ilmu Budaya, Universitas Udayana

Jln. Pulau Nias No.13, Dauh Puri Kelod, Kec. Denpasar Timur, Kota Denpasar, Bali

Pos-el : eldikhairulakbar@gmail.com, palupi_titasari@unud.ac.id, srijaya59@yahoo.com

\begin{tabular}{|c|c|}
\hline INFO ARTIKEL & ABSTRACT \\
\hline $\begin{array}{l}\text { Histori Artikel } \\
\text { Diterima : Agustus } 2021 \\
\text { Direvisi : September } 2021 \\
\text { Disetujui : November } 2021\end{array}$ & $\begin{array}{l}\text { The exotic relief that was found in Meduwe Karang temple is a symbolic } \\
\text { magic form of art. The relief has a meaning that's important to study } \\
\text { more because the relief itself holds stories and the meaning of its } \\
\text { deception. The study aims to depict the story behind the relief in }\end{array}$ \\
\hline $\begin{array}{l}\text { Keywords: } \\
\text { Erotic Relief, Visual } \\
\text { Language, Wimba, } \\
\text { Copulation, Fertility } \\
\text { Kata kunci: } \\
\text { Relief Erotis, Bahasa } \\
\text { Rupa, Wimba, } \\
\text { Sanggama, Kesuburan }\end{array}$ & $\begin{array}{l}\text { Meduwe Karang temple and to understand the meaning behind the } \\
\text { relief from the production based on the research that has been done. } \\
\text { This article is written using a qualitative method with visual language } \\
\text { analysis. So far, language analysis is still not much done, which makes } \\
\text { it necessary to do thorough research to study deeper the story behind } \\
\text { the depiction of each relief that is located on a religiously sacred } \\
\text { building using this type of analysis. The data collection is done through } \\
\text { literature review, surveys, and interviews. The analysis is done by } \\
\text { studying the wimba (image object) and the grammar inside (how to } \\
\text { arrange wimba so that can tell a story) the panels of the exotic relief. } \\
\text { The findings of this study show that the story form of the exotic relief } \\
\text { that is carved on the pelinggih walls of Meduwe Karang temple, depicts } \\
\text { a copulation scene with a background of nature. The depiction itself is } \\
\text { a form of sacred symbol which is included in a symbolic magic belief } \\
\text { that has a meaning of pleading, helping, protection, and fertility } \\
\text { especially in the agriculture and plantation field. }\end{array}$ \\
\hline
\end{tabular}

\section{ABSTRAK}

$\overline{\text { Relief erotis yang ditemukan di Pura Meduwe Karang merupakan salah satu }}$ bentuk karya seni rupa yang bersifat simbolis magis. Relief tersebut dipahatkan oleh para seniman masa lalu sebagai media komunikasi visual. Relief ini memiliki makna yang penting untuk dikaji lebih lanjut, karena relief tersebut memiliki cerita dan makna atas penggambaranya. Tujuan dilakukan penelitian ini adalah untuk menggambarkan cerita dalam relief erotis di Pura Meduwe Karang serta memahami makna relief tersebut dalam pembuatannya dengan berdasarkan pada penelitian yang telah dilakukan. Tulisan ini menggunakan metode penelitian kualitatif dengan analisis bahasa rupa. Sejauh ini analisis bahasa rupa masih belum banyak dilakukan, sehingga perlu dilakukan penelitian lebih lanjut untuk mengkaji lebih dalam mengenai cerita dari penggambaran masing-masing relief yang terdapat pada bangunan suci keagamaan dengan menggunakan analisis yang mengIndonesia ini. Pengumpulan data dilakukan melalui studi pustaka, survei, dan wawancara. Analisis dilakukan dengan cara mengkaji wimba (objek gambar) dan tata ungkapan dalam (cara menyusun wimba agar bisa bercerita) pada panil relief erotis. Hasil penelitian menunjukan bahwa bentuk cerita relief erotis yang dipahatkan pada dinding pelinggih Pura Meduwe Karang menggambarkan adegan sanggama dengan latar kejadian di luar ruangan (alam). Penggambaranya merupakan bentuk simbol suci yang termasuk dalam wujud kepercayaan simbolis magis yang memiliki makna sebagai bentuk permohonan pertolongan, perlindungan, dan kesuburan terutama dalam bidang pertanian dan perladangan. 


\section{PENDAHULUAN}

Seni rupa di Indonesia sudah berkembang sejak masa prasejarah. Salah satu bentuk seni rupa yang dibuat masyarakat prasejarah dan ditemukan di Indonesia berupa lukisan cadas yang dipahatkan pada dinding-dinding gua dengan menggunakan bahan alami, seperti yang ditemukan di wilayah Maros Sulawesi Selatan. Penggambaran lukisan cadas tersebut merupakan salah satu bukti perkembangan seni rupa paling awal di Indonesia yang memiliki makna di dalamnya, baik sebagai makna simbolik ataupun ornamental. Pencapaian bentuk karya seni rupa mengalami perkembangan yang pesat dan menojol pada periode Hindu-Buddha. Perkembanganya tampak pada estetika unsur kesenian yang sangat memengaruhi seluruh aspek kehidupan masyarakat Indonesia, seperti adanya pemahatan relief pada bangunan suci keagamaan (Sedyawati, 1995:250-252)

Relief merupakan suatu karya seni rupa yang berbentuk pahatan pada bangunan suci, seperti candi, pura, petirtaan, serta gua yang memiliki simbol dan makna tertentu. Pada bangunan suci seperti candi, relief memiliki arti biasanya sebagai upaya pelukisan suatu peristiwa atau cerita tertentu berupa ungkapan yang nyata atas ide atau gagasan dari benak seniman (Ayatrohaedi, 1978; Kusen, 1985:85). Pembuatan relief memiliki maksud dan peranan penting yang berfungsi sebagai bentuk media komunikasi visual sebagai ungkapan yang memiliki makna filosofis, historis, dan edukatif (Suliantoro, 1990).

Relief sebagai karya seni rupa merupakan salah satu bentuk media yang dipakai oleh para seniman masa lalu untuk menyampaikan pesan yang ingin disampaikan. Pesan tersebut biasanya mengandung ajaran tentang nilai-nilai kepahlawanan, keagamaan, cinta kasih, kesetiaan, dan sebagainya. Pengambaran cerita pada relief biasanya mengacu pada kitab susastra atau cerita lokal yang berkembang di lingkungan masyarakat yang dapat ditangkap dan dipahami dengan baik, sehingga apa yang digambarkan pada relief memiliki suatu nilai komunikatif yang memadai (Kusen, 1985:85).

Penggambaran relief banyak ditemukan di pura yang merupakan tempat beribadah umat Hindu. Relief tersebut biasanya dipahatkan pada bagian dinding pura. Adanya penggambaran relief yang bersifat erotis yang ditemukan di pura merupakan hal yang unik dan menarik untuk dilakukan kajian penelitian, karena penggambaranya masih dianggap tabu oleh masyarakat serta maknanya sering disamakan dengan pornografi.

Menurut Muller (dalam Darmojuwono 1994), erotis berasal dari kata eros dalam bahasa Yunani yang berarti Dewa Cinta. Eros memiliki kaitan dengan keindahan mengenai gambaran yang bersifat indrawi di dunia. Keindahan tersebut mencakup atas badan, pengetahuan, jiwa, moral, dan keindahan itu sendiri. Penggambaran relief erotis lebih mengarah pada perilaku serta keadaan atau suasana yang didasari oleh keinginan seksual tetapi, tidak semua penggambaran unsur erotis yang digambarkan mengakibatkan timbulnya nafsu birahi atau seksual pada pembacanya, karena relief tersebut mempunyai makna dan tujuan pemahatan tertentu (Hoed, 1994). 
Penggambaran relief erotis pada bangunan suci pura di Bali dapat ditemukan di Kabupaten Tabanan, yaitu di Pura Mas Magelah; Kabupaten Badung di Pura Buitan Kapal dan Pura Dalem Gede; Kabupaten Bangli di Pura Penunggekan; dan Kabupaten Buleleng di Pura Dalem Jagaraga dan Pura Meduwe Karang (Gede, 2000:105-108). Penggambaranya ada yang dipahatkan di halaman jabaan (halaman luar), jaba tengah (halaman tengah), dan jeroan (halaman dalam). Seperti yang ditemukan di Pura Meduwe Karang, Kabupaten Buleleng yang ditemukan di halaman jeroan pura.

Pura Meduwe Karang merupakan pura yang unik yang memiliki ciri khas tersendiri. Keunikan-keunikan yang ditemukan di Pura Meduwe Karang tampak pada tinggalan budayanya, seperti struktur bangunan, arca, dan relief. Ditemukanya pahatan relief erotis di Pura Meduwe Karang di halaman jeroan pura pada dinding pelinggih sebelah utara, selatan, dan barat membuat kesan pura ini menjadi unik, karena tidak semua pura yang tersebar di Bali dapat ditemukan pahatan relief erotis. Relief tersebut dibuat secara simbolis dengan gaya klasik muda Jawa Timuran. Relief dengan gaya klasik muda ini berkembang pada abad ke- 11-15 M dengan ciri-ciri pahatan reliefnya dangkal, bentuk penggambaranya simbolis, penggambaran tokoh selalu digambarkan menghadap ke samping, dan adanya kecenderungan untuk mengisi seluruh panil (Munandar, 2004:55).

Relief erotis yang dipahatkan di Pura Meduwe Karang digambarkan sebagai bentuk komunikasi visual yang perlu dilakukan penelitian lebih lanjut untuk mengungkapkan isi cerita dan makna dari pemahatan relief erotis tersebut. Hal yang dapat dilakukan adalah dengan menganalisis relief tersebut menggunakan analisis bahasa rupa yang dikembangkan oleh Primadi Tabrani (2012:3). Bahasa rupa merupakan suatu kaidah bahasa yang digunakan dalam menggambarkan unsur-unsur rupa dengan tujuan untuk memahami suatu cerita (Ambarawati, 2003: 37).

Penelitian tentang bahasa rupa pada relief di pura merupakan penelitian yang unik, karena sejauh ini penelitian terkait analisis bahasa rupa pada relief masih belum banyak dilakukan. Perlu dilakukan penelitian menggunakan analisis bahasa rupa yang lebih banyak lagi untuk mengkaji lebih dalam mengenai cerita dari penggambaran masing-masing relief yang ditemukan di pura atau bangunan suci yang tersebar di Indonesia dengan cara analisis yang meng-Indonesia ini, seperti penelitian yang telah dilakukan sebelumnya oleh Ismurdyahwati (2011), Harto (2014), dan Istanto (2017).

Berdasarkan uraian di atas, rumusan masalah dalam penelitian ini adalah bagaimana bentuk cerita yang ada pada panil relief erotis di Pura Meduwe Karang serta makna apa yang terkandung dalam penggambaran relief erotis tersebut. Tujuan dilakukan penelitian ini adalah untuk menggambarkan cerita dalam relief erotis di Pura Meduwe Karang serta memahami makna relief tersebut dalam pembuatannya. Penelitian menggunakan analisis bahasa rupa pada relief erotis di Pura Meduwe Karang merupakan penelitian yang baru dilakukan, sehingga diharapkan tulisan ini dapat menjadi landasan penelitian 
lanjutan untuk mengembangkan penelitian analisis bahasa rupa pada relief candi atau pura yang ditemukan di Indonesia, agar dapat memperkaya penelitian bahasa rupa yang masih belum banyak dilakukan oleh para ahli arkeologi.

\section{METODE}

Metode kualitatif dengan analisis bahasa rupa digunakan dalam penelitian ini. Metode ini sangat sesuai untuk menjawab permasalahan yang diajukan untuk mengetahui bentuk cerita dan makna penggambaran relief erotis di Pura Meduwe Karang. Objek yang dijadikan penelitian adalah relief erotis yang ditemukan di halaman jeroan Pura Meduwe Karang, Kabupaten Buleleng yang dipahatkan pada dinding pelinggih sebelah utara, timur, dan barat.

Pengumpulan data dilakukan dengan mencari data kepustakaan seperti laporan penelitian, jurnal, artikel, serta buku yang memiliki kaitan dengan objek penelitian. Survei dilakukan di Pura Meduwe Karang, Kabupaten Bulelelng untuk mengumpulkan data terkait bentuk dan ukuran relief. Wawancara dilakukan terhadap tokoh yang memiliki pengetahuan terkait pura Meduwe Karang guna mendukung data penelitian.

Analisis data dilakukan dengan menggunakan teori analisis bahasa rupa yang dikemukakan oleh Tabrani (1991). Analisis ini sangat sesuai diaplikasikan pada relief erotis yang ditemukan di Pura Meduwe Karang, karena relief ini memiliki cerita dan makna dalam penggambaranya, serta relief tersebut termasuk ke dalam bentuk bahasa rupa tradisi yang memiliki sifat dua dimensi statis tradisional. Bentuk cerita dan makna pemahatan relief erotis dalam analisis bahasa rupa dapat diketahui dengan cara memahami unsur wimba dan tata ungkapan yang terdapat pada panil relief tersebut. Wimba merupakan suatu obyek yang dicandera (objek gambar), sedangkan tata ungkapan adalah cara menyusun wimba dan cara wimba-nya dalam satu bidang gambar sehingga bercerita (Tabrani, 2012:13).

Wimba dapat dibedakan antara 'isi wimba' dan 'cara wimba', sedangkan pada tata ungkapan dapat dibedakan antara 'tata ungkapan dalam' dan 'tata ungkapan luar'. Secara keseluruhan langkah yang dilakukan untuk menganalisis bahasa rupa pada relief erotis di Pura Meduwe Karang dapat dilakukan dengan cara memahami 'isi wimba', 'cara wimba', dan 'tata ungkapan dalam'. Pembacaan dengan menggunakan 'tata ungkapan luar' tidak dilakukan pada relief ini, karena relief erotis yang ditemukan di Pura Meduwe Karang bukan merupakan relief berseri melainkan relief tunggal sehingga pembacaan 'tata ungkapan luar' tidak perlu dilakukan.

\section{HASIL DAN PEMBAHASAN}

\section{Gambaran Umum Pura Meduwe Karang}

Secara administratif Pura Meduwe Karang terletak di Desa Kubutambahan, Kecamatan Kubutambahan, Kabupaten Buleleng, Provinsi Bali. Pura Meduwe Karang memiliki arti sebagai pura tanah atau pura tegalan yang memiliki kaitan 
dengan orang-orang yang bekerja di bidang pengolahan tanah. Pura ini difungsikan sebagai sarana pemujaan bagi masyarakat yang melakukan pekerjaan di bidang pertanian atau orang yang memiliki lahan pertanian (Artanegara, 2019).

Kronologi pembangunan Pura Meduwe Karang sampai saat ini masih belum diketahui secara pasti, karena tidak terdapatnya prasasti atau candrasengkala yang ditemukan di bangunan pura ini. Menurut keterangan dari Komang Sugiada selaku TIS (Touris Information Service) wilayah Buleleng, Pura Meduwe Karang dibangun sekitar tahun 1880. Jika melihat relief yang dipahatkan pada bangunan Pura Meduwe Karang, seperti adanya pahatan relief Raja Klungkung, Raja Buleleng, serta relief pengendara sepeda besar kemungkinan pura ini telah digunakan sejak zaman kerajaan Buleleng (abad ke-17-19 Masehi), dimana Klungkung dianggap sebagai kerajaan tertinggi (abad ke-17 sampai awal abad ke-20 Masehi), sehingga dipahatkanlah relief-relief tersebut (Arainikasih, 2006:122-123).

Konstruksi bangunan Pura Meduwe Karang terbagi menjadi tiga halaman, sama halnya dengan konstruksi bangunan pura lainya yang ditemukan di Bali. Bangunan ini dibagi menjadi jabaan (halaman luar), jaba tengah (halaman tengah), dan jeroan (halaman dalam) yang makin ke dalam halaman tersebut makin tinggi dengan arah hadap bangunan pura ke arah barat. Bangunan-bangunan yang terdapat di kompleks Pura Meduwe Karang berupa bangunan seperti pelinggih jero pekandel, bale petanding, dua bale piasan, pelinggih utama, dan pawaregan (Arainikasih, 2006:140).

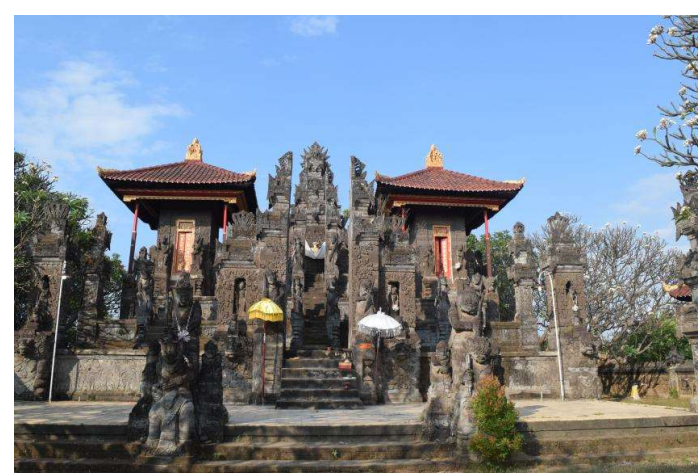

Gambar 1. Konstruksi Bangunan Pura Meduwe Karang (Sumber: Dokumentasi Eldi)

Arca-arca di Pura Meduwe Karang ditempatkan di setiap halaman pura, di mana penggambaran arca tersebut merupakan tokoh-tokoh dari epos Ramayana, arca-arca Rangda, dan arcaarca manusia biasa yang paling banyak menggambarkan tokoh wanita (Arainikasih, 2006:139-140). Relief di Pura Meduwe Karang dipahatkan pada bangunan pelinggih utama, baik pada bataran pelinggih, dinding, maupun tiang serta di bagian belakang padmasana. Relief yang digambarkan ada berdasarkan kitab susastra dan ada pula relief yang menggambarkan kehidupan masyarakat lokal. Penggambaran relief erotis merupakan temuan yang menarik dari pura ini, karena penggambarannya masih dianggap tabu oleh masyarakat Buleleng. Relief ini ditemukan di halaman jeroan pura pada di dinding sebelah utara, selatan, dan barat pelinggih.

Penggambaran relief di Pura Meduwe Karang dipahatkan secara dangkal (bas relief). Arah hadap pahatan ada yang orientasi ke depan serta ada pula yang mengarah ke samping seperti wayang. Secara garis besar ciri-ciri pahatan relief yang ditemukan di Pura Meduwe Karang memiliki banyak 
kesamaan dengan ciri-ciri relief yang dipahatkan pada gaya klasik muda (Era Jawa Timuran). Menurut Munandar (2004:55), gaya relief klasik muda memiliki karakteristik, yaitu i) bentuk pahatan yang dangkal, dengan ketebalan relief satu per empat dari ketebalan media; ii) bentuk penggambaran figur manusia, hewan, dan tumbuhan bersifat simbolis yang penggambaranya kerap kali tidak proporsional dan kaku; iii) panil relief sepenuhnya diisi dengan hiasan yang penuh (adanya kecenderungan diisi dengan bentuk lain); dan iv) penggambaran tokoh seperti figur manusia dan hewan digambarkan menghadap ke samping seperti wayang kulit.

\section{Analisis Bahasa Rupa Relief Erotis di Pura Meduwe Kar nang}

Ilmu Bahasa Rupa lahir di Indonesia pada sekitar tahun 1980-an yang dipelopori oleh Primadi Tabrani (2012:3) yang berkulminasi dengan disertasi disertasinya atas studi perbandingan tentang bahasa rupa prasejarah, primitif, tradisional, anak, dan bahasa modern. Ilmu ini dapat digunakan untuk memahami isi berbagai jenis gambar prasejarah, primitif, relief, gambar anak, dan lainya secara praktis tanpa teks

Bahasa rupa dapat dibedakan antara wimba dan tata ungkapan. Wimba merupakan suatu obyek yang dicandera (objek gambar), sedangkan tata ungkapan adalah cara menyusun wimba dan cara wimba-nya dalam satu bidang gambar sehingga bercerita (Tabrani, 2012:13). Wimba sendiri dibedakan antara isi wimba dan cara wimba, sedangkan dalam tata ungkapan dibedakan antara tata ungkapan dalam dan tata ungkapan luar (Tabrani, 2012:18). Isi wimba merupakan objek apa yang digambar, seperti contoh jika terdapat gambar sapi pada relief maka isi wimba tersebut adalah sapi. Cara wimba adalah cara dengan apa wimba itu digambar, seperti contoh jika terdapat gambar kuda yang blabar yang dinamis pada relief, berarti cara wimba-nya adalah kuda tersebut sedang bergerak. Tata ungkapan dalam merupakan cara yang dilakukan dalam menyusun berbagai wimba termasuk di dalamnya terdapat cara wimba agar bisa bercerita dalam satu gambar (Tabrani, 2012:30).

Analisis bahasa rupa pada relief erotis yang ditemukan di dinding Pura Meduwe Karang dapat dilakukan dengan cara memahami isi wimba, cara wimba, dan tata ungkapan dalam pada panil relief tersebut. Berhubung relief erotis yang ditemukan di Pura Meduwe Karang bukan merupakan satu panil kesatuan melainkan relief tunggal (ceritanya berdiri sendiri), maka analisis tata ungkapan luar tidak dilakukan. Berikut bentuk cerita pada panil relief erotis uang ditemukan di dinding Pura Meduwe karang berdasarkan hasil analisis bahasa rupa. 


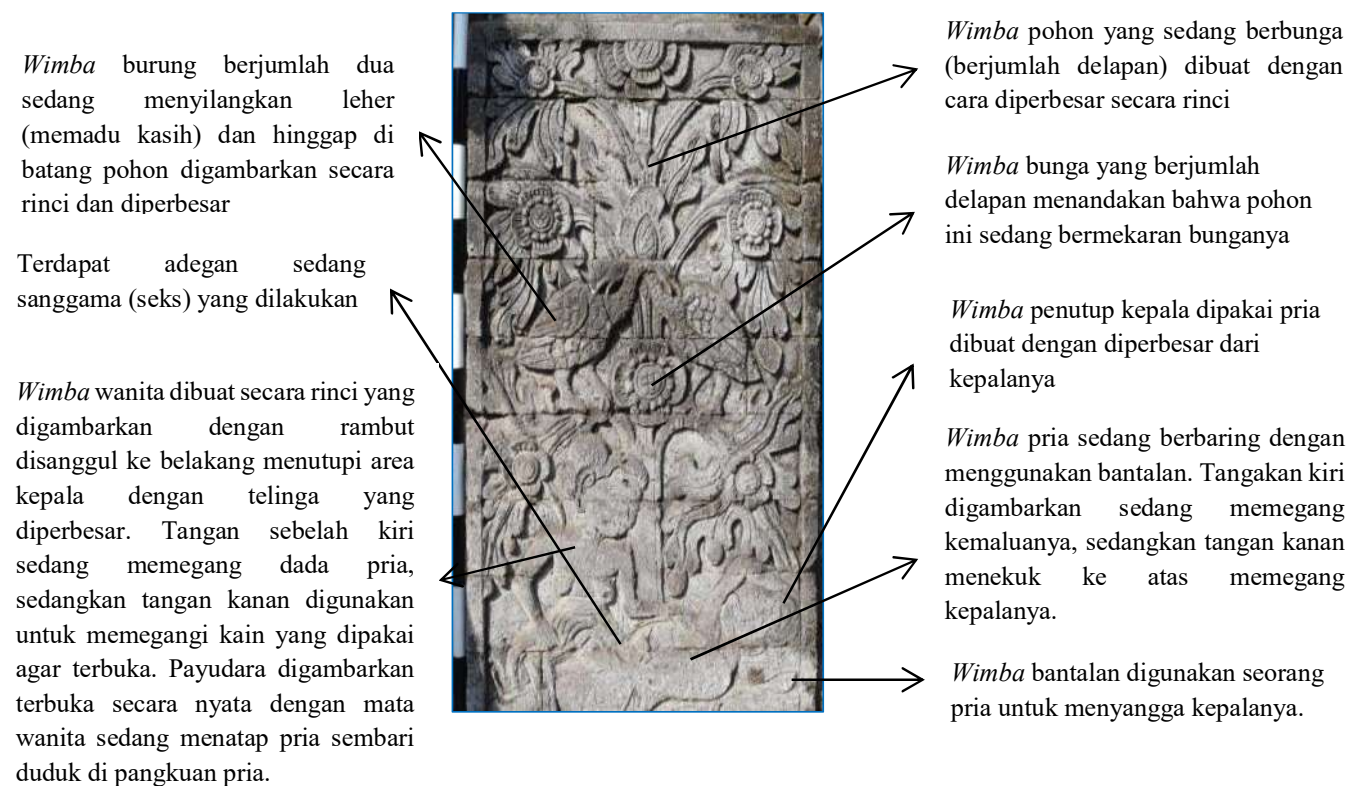

Gambar 2. Analisis Bahasa Rupa Relief Dinding Pelinggih Pura Sebelah Barat (Sumber: Dokumentasi Dan Analisis Eldi)

Relief erotis di dinding pelinggih sebelah barat ditemukan di halaman jeroan pura dengan ukuran panjang panil relief $96 \mathrm{~cm}$ dan lebar $56 \mathrm{~cm}$ (Gambar 2). Relief ini digambarkan dalam bentuk yang dangkal dengan tebal seperempat dari ketebalan media batuanya dengan arah hadap figur ke samping. Bentuk figur yang ditemukan dalam relief di dinding ini adalah tokoh pria, wanita, burung, pohon, dan bunga yang digambarkan secara simbolis. Berdasarkan analisis bahasa rupa yang dilakukan, isi cerita pada panil relief ini menggambarkan dua orang tokoh, wanita dan pria, yang sedang melakukan adegan sanggama dengan latar kejadian di luar ruangan (alam).

Tokoh pria digambarkan sedang dalam posisi berbaring dengan menggunakan bantalan sebagai penyangga kepalanya. Tangan kirinya sedang memegang kemaluannya, menghadap ke arah wanita yang tengah duduk di atas pangkuannya yang juga sama-sama tersenyum dan saling menatap. Tokoh wanita itu sendiri digambarkan selayaknya wanita dewasa, mempunyai rambut lebat yang disanggul ke belakang dan menutupi area sekitar kepalanya serta telinga dengan ukuran yang besar. Setengah pakaiannya terbuka, menampilkan buah dada miliknya. Tangan kirinya memegang dada pria yang terbaring di depannya lalu tangan kanannya memegang kain yang digunakan untuk menutupi bagian bawah tubuh wanita tersebut.

Dua ekor burung yang bertengger di atas pohon dan saling menyilangkan lehernya sebagai tanda cinta seolah menggambarkan suasana penuh kasih yang sama seperti pria dan wanita yang sedang bersanggama tersebut. Bungabunga yang bermekaran di pohon 
menambah keromantisan yang terjalin di antara mereka.

\section{Relief Dinding Pelinggih Pura Sebelah} Utara

Relief erotis di dinding pelinggih sebelah utara ditemukan di halaman jeroan pura dengan ukuran panjang panil relief $96 \mathrm{~cm}$ dan lebar 56cm (Gambar 3). Relief ini digambarkan dalam bentuk yang dangkal dengan tebal seperempat dari ketebalan media batuanya dengan arah hadap figur ke samping. Bentuk figur yang ditemukan pada relief di dinding ini adalah tokoh pria, wanita, unggas, pohon, dan bunga yang secara keseluruhan bentuknya digambarkan secara simbolis.

Berdasarkan analisis bahasa rupa yang dilakukan, isi cerita pada panil relief ini menggambarkan tokoh pria dan wanita yang sedang melakukan adegan sanggama dengan posisi berdiri. Masingmasing pakaian yang digunakan tersingkap setengahnya tanpa mengenakan atasan pakaian. Sang pria yang menggunakan penutup kepala berdiri di belakang sang wanita. Posisi kakinya melakukan kuda-kuda di mana posisi kaki kiri di depan kaki kanan, sedangkan kedua tangannya digunakan untuk memegangi pinggul wanita yang disetubuhinya. Tokoh wanita digambarkan dengan gaya rambut terurai terlihat sedang berdiri tanpa mengenakan atasan pakaian sehingga buah dadanya terlihat menonjol. Posisi wanita digambarkan sedikit membungkuk ke depan sambil kedua tangannya memegang batang pohon di depannya dengan pandangannya sedikit menoleh ke belakang, menatap pria yang menyetubuhinya.

Bunga-bunga yang bermekaran serta daun yang tumbuh lebat di pohon mendukung suasana penuh cinta yang terjalin di antara kedua pria dan wanita yang sedang memadu kasih. Sejenis unggas terlihat sedang menjaga aktivitas

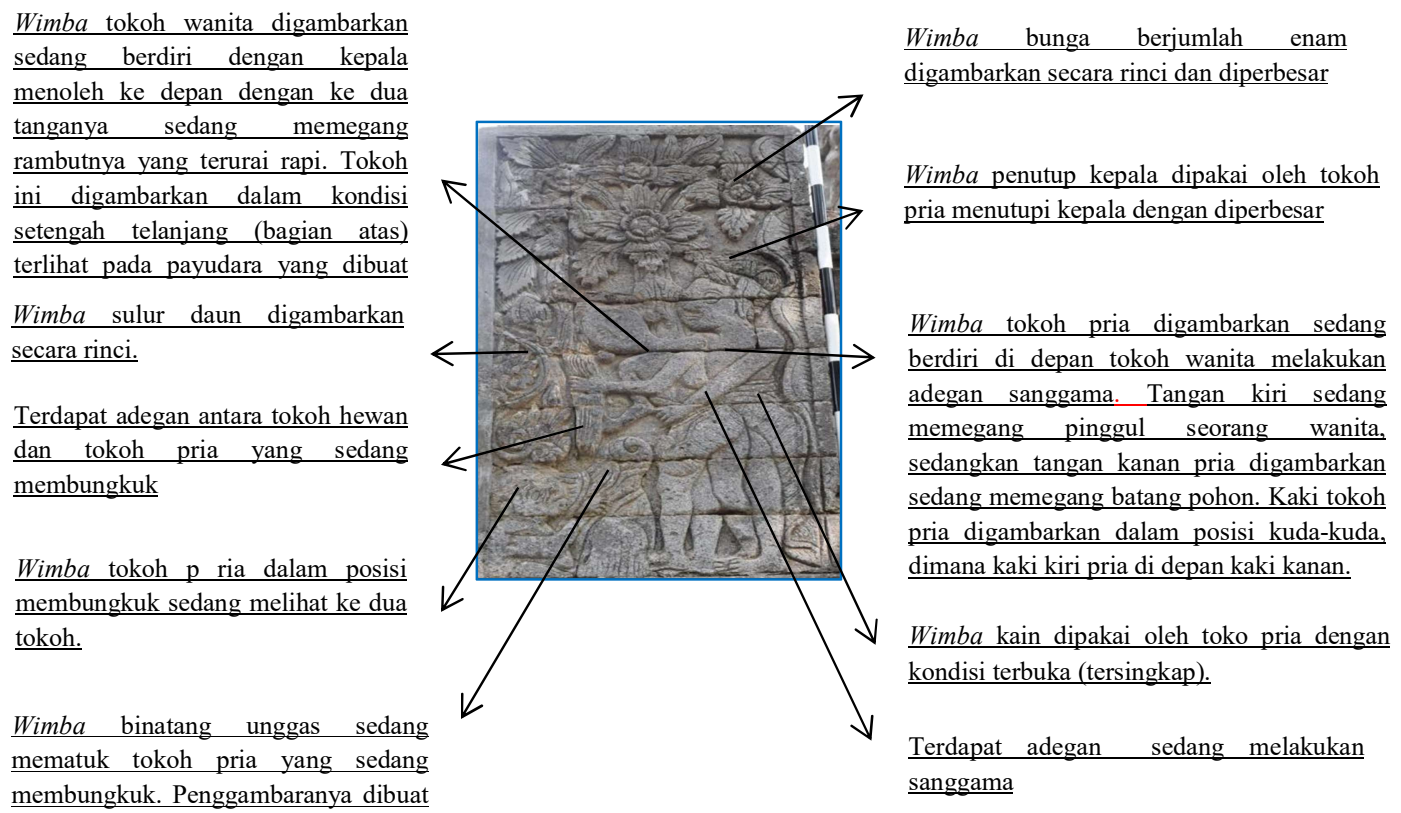

Gambar 3. Analisis Bahasa Rupa Relief Dinding Pelinggih Pura Sebelah Utara (Sumber: Dokumentasi dan Analisis Eldi) 
mereka dari seorang pria bertubuh kecil yang seperti hendak mengintip.

3. Relief Dinding Pelinggih Pura Sebelah Timur tersenyum ketika melakukan aksinya, menunjukkan kalau dirinya sangat menikmatinya. Sementara wanita yang disetubuhinya berada dalam posisi

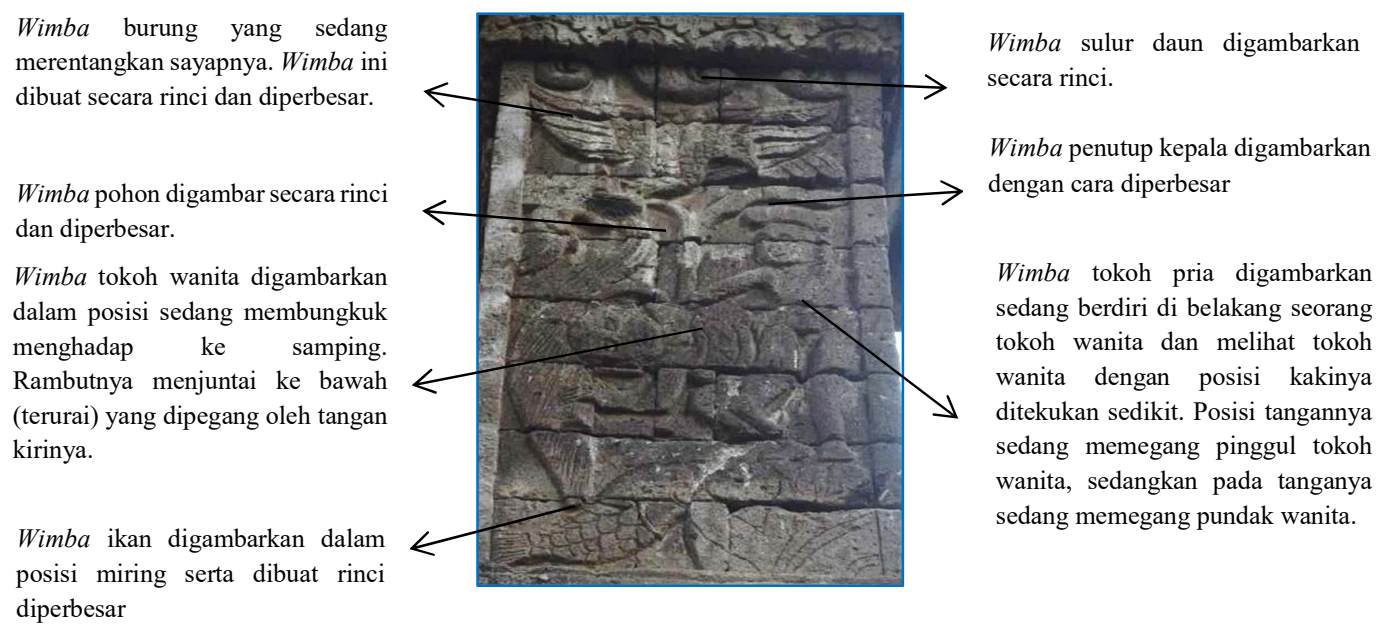

Gambar 4. Analisis Bahasa Rupa Relief Dinding Pelinggih Pura Sebelah Timur (Sumber: Dokumentasi dan Analisis Eldi)

Relief erotis di dinding pelinggih sebelah timur ditemukan di halaman jeroan pura dengan ukuran panjang panil relief $88 \mathrm{~cm}$ dan lebar 41,2 $\mathrm{cm}$ (Gambar 4). Relief ini digambarkan dalam bentuk yang dangkal dengan tebal seperempat dari ketebalan media batuannya dengan arah hadap figur ada yang ke samping dan ke depan. Bentuk figur yang ditemukan dalam relief di dinding sebelah timur terdiri atas tokoh pria, wanita, ikan, burung, dan suasana alam yang secara keseluruhan bentuknya digambarkan secara simbolis.

Berdasarkan analisis bahasa rupa yang dilakukan, isi cerita pada panil relief ini menggambarkan sepasang pria dan wanita sedang melakukan adegan sanggama di hutan. Posisi si pria sedang berdiri memegang pinggul si wanita dengan menggunakan tangan kirinya kemudian tangan kanan memegang bagian bahunya. Pria tersebut terlihat membungkuk dengan kepala menghadap ke samping dengan tangan kirinya memegang rambutnya yang terjuntai ke bawah.

\section{Makna Penggambaran Relief Erotis}

Secara keseluruhan cerita pada panil relief erotis yang dipahatkan pada dinding Pura Meduwe Karang menggambarkan adegan sanggama (seks). Agama Hindu memandang seks sebagai bagian dari salah satu empat tujuan hidup manusia (catur purusa artha) dan seks juga merupakan bagian dari yoga yang dapat menghubungkan antara atma dan paramatma (Sumertini, 2020:2-7). Adegan seks merupakan bentuk penyatuan antara unsur feminin dan maskulin (binary opposition) yang akan menghasilkan kekuatan tertinggi bagi penciptaan (Cahyono 2012:23). Penggambaranya dalam relief termasuk ke dalam wujud kepercayaan simbolis 
magis yang akan menghasilkan kekuatan tertinggi, sehingga bentuk penggambaranya merupakan simbol suci dalam agama Hindu. Penggambaran adegan seks dalam relief merupakan suatu simbol yang digunakan untuk menyuarakan pesan keagamaan yang berkenaan dengan etos atau pandangan hidup sesuai dengan keinginan para pelaku upacara. Dalam hal ini penggambaranya memiliki pesan adanya kepercayaan terkait unsur-unsur keselamatan, kesuburan, kelahiran, dan penolak bahaya (Atmodjo, 1983:13; Rema, 2011:118).

Hasil penelitian menunjukan bahwa relief erotis yang ditemukan di Pura Meduwe Karang merupakan salah satu simbol pertanda seks yang dibuat oleh seniman masa lalu yang digunakan sebagai ritus keagamaan masyarakat Hindu Buleleng. Pembuatanya dipakai sebagai media yang dihubungkan dengan kepercayaan agama Hindu yang mengandung makna untuk memperoleh pertolongan, perlindungan, dan kesuburan bagi masyarakat, terutama masyarakat agraris di sekitar pura.

Simbol lain yang ditemukan dalam cerita relief erotis di Pura Meduwe Karang yang bentuknya melambangkan kesuburan adalah adanya penggambaran ragam hias yang mendukung alur cerita relief tersebut. Ragam hias seperti penggambaran pohon berbunga, adegan burung yang sedang menyilangkan leher, serta penggambaran suasana alam merupakan simbol lain yang memiliki makna terkait kesuburan.

Bentuk penggambaran adegan cerita pada panil relief erotis yang ditemukan di Pura Meduwe Karang, baik bentuk adegan sanggama atau ragam hias yang ditampilkan memiliki makna simbolis magis yang sesuai dengan fungsi pura. Pendirian pura dimaksudkan untuk masyarakat yang bekerja di bidang pertanian dan perladangan, sehingga permohonan pertolongan, perlindungan, dan kesuburan tercermin penggambaranya pada panil relief erotis yang dipahatkan pada dinding Pura Meduwe Karang.

Berdasarkan analisis bahasa rupa dengan cara memahami isi wimba, cara wimba, dan tata ungkapan dalam pada panil relief erotis yang ditemukan di Pura Meduwe Karang, secara keseluruhan cerita yang digambarkan pada panil reliet tersebut merupakan cerita adegan sanggama. Agama Hindu memandang sanggama merupakan bagian dari tujuan hidup manusia (catur purusha arta) dan bagian dari yoga, sehingga hal ini menandakan bahwa adegan sanggama suci kedudukanya. Adanya pahatan relief erotis adegan sanggama yang ditemukan di Pura Meduwe Karang merupakan bentuk simbol suci yang termasuk dalam wujud kepercayaan simbolis magis yang memiliki makna sebagai bentuk permohonan pertolongan, perlindungan, dan kesuburan terutama dalam bidang pertanian dan perladangan yang dipercayai oleh masyarakat Hindu Buleleng sejak dahulu sampai sekarang.

\section{PENUTUP}

Tinggalan yang ditemukan di Pura Meduwe Karang merupakan salah satu bentuk kreativitas yang unik yang dibuat oleh seniman pada masa lalu. Keunikan ini merupakan salah bentuk ciri khas dari seni Buleleng yang ciri-cirinya menggambarkan bentuk kearifan lokal masyarakat Buleleng. Seperti halnya 
adanya penggambaran relief erotis yang ditemukan di halaman jeroan dinding pelinggih Pura Meduwe Karang yang berjumlah tiga panil relief. Relief tersebut dipahatkan pada dinding sebelah utara, timur, dan barat palinggih pura secara simbolis dengan bentuk pahatanya menyerupai wayang. Bentuk cerita yang dipahatkan pada panil relief tersebut secara keseluruhan menggambarkan adegan sanggama yang dilakukan secara romantis dengan latar kejadian di luar ruangan (alam).

Penggambaran adegan sanggama dalam relief merupakan bentuk simbol suci yang termasuk dalam wujud kepercayaan simbolis magis. Penggambaranya oleh para seniman masa lalu dijadikan sebagai media komunikasi visual dalam rangka memperoleh pertolongan, perlindungan, dan kesuburan, dalam hal ini maknanya sebagai permohonan kesuburan dalam bidang pertanian dan perladangan sesuai dengan fungsi didirikanya pura tersebut.

Penelitian bahasa rupa dalam rangka mengungkap cerita dan makna yang terkandung dalam penggambaran relief erotis yang ditemukan di Pura Meduwe Karang ini menunjukan bahwa tidak semua relief erotis mengandung kesan yang tidak baik (pornografi), tetapi didalamnya terkandung makna dan nilai yang sangat suci. Seyogyanya bagi masyarakat pada masa sekarang dapat melihat lebih dalam lagi mengenai makna dan nilai baik yang terkandung pada penggambaran relief erotis yang dipahatkan pada bangunan suci. Bagi peneliti, tulisan ini dapat dijadikan landasan penelitian lanjutan untuk dilakukan pengembangan penelitian analisis bahasa rupa pada relief yang belum banyak dilakukan oleh para ahli arkeologi, sehingga dengan melakukan hal itu dapat memperkaya kajian analisis bahasa rupa yang meng-Indonesia ini.

\section{DAFTAR PUSTAKA}

Ambarawati. 2003. Bahasa Rupa Cerita Sudamala pada Candi Sukuh. (Skripsi). Semarang: Universitas Negeri Semarang

Arainikasih, Ajeng Ayu. 2006. Tinjauan Arsitektur dan Fungsi Pura Meduwe Karang. (Skripsi). Depok: Universitas Indonesia

Artanegara. 7 Februari 2019. Situs Pura Meduwe Karang. https://kebudayaan.kemdikbud.go.id/bpcbbali/situs-pura-meduwe-karang/ diakses 27 Juli 2021.

Atmodjo, M.M. Soekarto K. 1983. Catatan Singkat Mengenai Ngelmu Katuranggan (Fisiognomi) dalam Masyarakat Jawa. Yogyakarta: Proyek Javanologi.

Ayatrohaedi. 1978. Kamus Istilah Arkeologi. Jakarta: Proyek Penelitian Bahasa dan Sastra Indonesia dan Daerah

Cahyono, M. Dwi. 2012. Makna dan Fungsi Simbol Seks dalam Ritus Kesuburan Masa Majapahit. Amerta, Jurnal Penelitian Dan Pengembangan Arkeologi, 30(1), 19-44. https://doi.org/10.24832/amt.v30i1.397 
Darmojuwono, Setiawati. 1994. "Erotisme dalam Bahasa" dalam Lembaran Sastra (Edisi Khusus). Depok: Universitas Indonesia.

Gede, Dewa Kompiang. 2000. Relief Erotis di Pura Dalem Penonggekan Bangli. Forum Arkeologi 13 (1) 103-111. http://dx.doi.org/10.24832/fa.v13i1.131

Harto, Dwi Budi. 2014. "Analisis Bahasa Rupa Relief Jataka Candi Borobudur” dalam Seminar Nasional Seni Tradisi hal. 25-42. Jakarta: Universitas Trisakti

Hoed, Benny H. 1994. "Erotisme dalam Bahasa: Sebuah Kajian Linguistik dan Semiotik" dalam lembaran Sastra (Edisi Khusus). Depok: Universitas Indonesia.

Ismurdyahwati, Ika. 2011. Bahasa Rupa Relief Candi di Komplek Plaosan Lor. Panggung: Jurnal Ilmiah Seni dan Budaya, 21(4), 368-374.

Istanto, Riza. 2017. Bahasa rupa Relief Kalpataru Pada Candi Prambanan. (skripsi). Semarang: Universitas Negeri Semarang

Kusen. 1985. Kreativitas dan Kemandirian Seniman Jawa dalam Mengolah Pengaruh Budaya Asing: Studi Kasus Tentang Gaya Seni Relief Candi di Jawa Anta ra Abad IX-XVI Masehi. Yogyakarta: Proyek Penelitian dan Pengkajian Kebudayaan Nusantara (Javanologi).

Munandar, Agus Aris. 2004. Karya Sastra Jawa Kuno Yang Diabadikan Pada Relief CandiCandi Abad Ke-13 - 15 M. Jurnal MAKARA, Sosial Humaniora, 8(2), 54-60.

Rema, I Nyoman. 2011. Kama dalam Kehidupan Kajian Filosofis Simbolis. Forum Arkeologi, 23 (2), 112-119. http://dx.doi.org/10.24832/fa.v24i2.136

Sedyawati, Edi. 1995. "Kesenian dalam Masyarakat Indonesia" dalam kumpulan Makalah 1993-1995 Direktur Jenderal Kebudayaan Prof Dr. Edi Sedyawati. Jakarta: Direktorat Jenderal Kebudayaan, Departemen Pendidikan dan Kebudayaan

Suliantoro, Bernadus Wibowo. 1990. Nilai Estetis Candi Prambanan. Yogyakarta: Fakultas Filsafat Universitas Gadjah Mada.

Sumertini, Ni Wayan. 2020. Garbhadhana Samskara (Perspektif Seks dalam Veda). Sanjiwani: JurnalFilsafat,11(1), 1-11. https://doi.org/10.25078/sjf.v11i1.1528

Tabrani, Primadi. 1991. Meninjau Bahasa Rupa Wayang Beber Jaka Kembang Kuning dari Telaah Cara Wimba dan Tata Ungkapan Bahasa Rupa Media Rupa Rungu Dwimatra Statis Modern, dalam Hubungannya dengan Bahasa Rupa Gambar Prasejarah, Primitip, Anak, dan Relief Lalitavistara Borobudur. (Disertasi). Bandung: Institut Teknologi Bandung.

Tabrani, Primadi. 2012. Bahasa Rupa. Bandung: Kelir 